\title{
Leadership of the principal in improving the professional competence of teachers in the digital age
}

\author{
Novi Andri Yani ${ }^{1}$, Muhammad Kristiawan ${ }^{2}$, Alfroki Martha $^{3}$ \\ ${ }^{1}$ Sekolah Menengah Atas Negeri 4 OKU, Jakarta, Indonesia \\ ${ }^{2}$ Universitas Bengkulu, Indonesia \\ ${ }^{3}$ Universitas PGRI Palembang, Indonesia
}

\section{Article Info}

\section{Article history:}

Received Jul 12 $2^{\text {th }}, 2021$

Revised Aug $10^{\text {th }}, 2021$

Accepted Aug 30 ${ }^{\text {th }}, 2021$

\section{Keyword:}

Leadership

Increase

Competence

Professional

\begin{abstract}
The achievement of the vision, mission and objectives of education depends on the wisdom and leadership skills of the principal as the leader of the education unit. While in general, this research aims to (1) Describe the leadership of the principal in improving the professional competence of teachers in the digital age. (2) Know the supporting and inhibiting factors of the principal in improving the professional competence of teachers in the digital age. The result of this research was obtained that the implementation of the type of leadership of the principal at SMA Negeri 4 OKU by the principal received a good response from subordinates, it's namely democratically, he always gave a good example to the teacher, so there is an improvement in the competence of the teacher's personality, delegate the teachers incidental related to the duties of officially and provide motivation to students, and open attitude becomes a place of consultation and implementation through decision making related to increasing the professionalism of teachers through meetings or deliberations, show how the way teachers are happy to carry out the verdict and feel satisfaction. The supporting factor of the principal's leadership type in improving the professional competence of teachers at SMA Negeri 4 OKU is adequate from infrastructure facilities, thus supporting the teaching, training or learning process in schools. Furthermore, the obstacles encountered include, the limitations of teacher training programs outside office hours, there are still some teachers who are not active, and the results of the training can not affect their friends, then in the rules that have been determined there are still teachers who are less disciplined.
\end{abstract}

(C) 2021 The Authors. Published by IICET.

This is an open access article under the CC BY-NC-SA license (https://creativecommons.org/licenses/by-nc-sa/4.0

\section{Corresponding Author:}

Yani, N. A.

Sekolah Menengah Atas Negeri 4 OKU, Jakarta, Indonesia

Email: noviesarobu6@gmail.com

\section{Introduction}

The law Number 20 in 2003 that is concerning about the National Education System (UU Sisdiknas), give the mandate of revolution in the education process in Indonesia to print human resources (HR) those are relevant to the needs, conditions and situations of the community. The mandate is contained in the policy of 2013 curriculum. The policy is as a strategic step for the implementation of the dynamic education process in Indonesia. The process of running educational updates, it positions teachers as an important factor. Thus, serious attention is needed to update the education process so there is an improvement in the professional ability of teachers by showing maximum performance (Mulyasa, 2004). 
That the school leader is seen as a special position. The position of school principal is the same as the other managers (Djafar, 2013). In their book with entitled Education Management, that each position shows the status of the responsibility of the holder (Rivai \& Murni, 2010)[3]. The status shows the role that it should be played by the officials. The headmaster take on the main role, it distinguishes him from other positions, because the headmaster has a role as a leader in the education unit. The integrity, accomplishment of the vision, mission and objectives of education depend on the principal's wisdom and leadership skills. It is caused, the headmaster is as a professional official in the school organization with the role of regulating all sources of the organization and coordinating teachers in educating students in order to achieve educational goals. Through a professional attitude, the headmaster needs to increase the professionalism of education personnel so that it makes it easier to carry out tasks according to their functions. The leadership it functions in the organization, they are focusing on the objectives, design and mission of the organization, organizational cultural development, empowerment of subordinates, product development of the organization, acting as a conductor that is organizing and synergize subordinates in carrying out their duties (Sumitro, 2012).

The most important component of education is teachers. In the context of education, the teachers have a strategic role. It seen from the science and technology that transferred as well as educating with a variety of positive values through accuracy and guidance. Teachers play a role in learning with a huge contribution to the success of learning in schools. The role of teachers in helping the development of learners to achieve life goals. with the knowledge, so that a person is able to change his quality of life into a better human being.

Professional teachers should have teacher competencies obtained by pursuing teacher education such as (S1-PGSD, S1 Education, AKTA Education), obtained from special education (Kristiawan et al., 2017) [5]. The teacher competence is obtained by taking a professionalization program followed by someone that undergoing the profession (pre-service training or pre-position) and after carrying out the profession (in-service training). Based on the result of observation in several high schools in Ogan Komering Ulu Regency, there are many professional teachers, supported by facilities and infrastructure. However, the percentage of students' interest and achievements of SMAN 4 OKU is more prominent than some high schools. Thus, the author chose SMN 4 OKU as the object of research.

SMAN 4 OKU is a favorite high school and the only referral school in OKU regency based on the Governor Decision of South Sumatra No. 259/KPTS/DISDIK/2020 about Referral High School in South Sumatra Province. In this case, efforts to improve the professional ability of teachers have been carried out by the headmaster to improve the quality by attending various trainings, supervision, postgraduate studies, and coaching from the education office. Thus, it can be seen from its application in improving the spirit of work ethic towards principals and teachers in daily activities up to the achievement of current achievements.

The reality in the field has shown some of the achievements that is achieved by SMAN 4 OKU, from academic to non-academic achievements. From this, the author wanted to explore the problems that arise in the scope of the school related with the way of headmaster's leadership to improve the professionalism of teachers at SMAN 4 OKU entitled "Leadership of The Principal in Improving Teacher Professional Competency (Leadership in the Digital Age)"

The problem formulation in this study is as follows. (1) How is the headmaster's leadership in improving the professional competence of teachers in the digital age?. (2) What are the factors supporting and inhibiting the headmaster in improving the professional competence of teachers in the digital age? While in general, this research aims (1) To describe the leadership of the headmaster in improving the professional competence of teachers in the digital age. (2) To determine the supporting and inhibiting factors of the headmaster in improving the professional competence of teachers in the digital age.

\section{The Headmaster's Leadership}

Explained that the headmaster's definition is the functional teacher who is assigned to lead the school, where there is an implementation of the teaching and learning process, or a place of interaction between teachers and students (Kristiawan et al., 2017). That the responsibility and function of the headmaster as the leader of the educational institution can be effective if it is able to carry out a leadership process that affects, encourages and moves the activities of the group (Dahlan, 2014).

From this explanation, it can be concluded that the headmaster is the highest leader of the educational institution with responsibility for everything related to the continuity operation of the school in order to realize the objectives of the school. A principal should be able to ensure that everything in the management of the educational institution is done well, it is as well as the planning and implementation of the curriculum, the availability and utilization of teacher resources, the acceptance of learners, fostering good school relations with parents, and then scoring quality graduates. The vital element of the educational institution, it is namely the 
principal as the determinant of the quality of the institution, it can be equated with the commander of education by carrying out the function of control with various patterns of educational and teaching activities.

\section{The Headmaster Managerial Concept}

In order to explain the meaning of leadership, so first put forward from one's point of view in understanding the nature of leadership, then based on the understanding, it can be known how to formulate and define leadership. It is reviewed from the history of its development in his book, Administration and Supervision of Education (Ananda \& Banurea, 2017; Sumarni \& Tamsah, 2017), there are 3 concepts of leadership, it is namely:

1. The concept that considers with leadership as the ability and various traits of carrying from birth that exist in a leader. Based on this concept, the meaning of leadership is seen as traits within the individual leader. So that one can become a leader, because it has been born as a leader and not because it is educated to lead (Leaders were horned and not made). This concept is the longest concept of leadership that is adopted. It is also embraced in people's lives today the concept can still be clearly seen. The view of the agrarian society feudal, has the presumption of a person who appointed as a leader because it is considered to have a good nature or potentially lead even because of descendants. It is expected as an example to others. The concrete examples can look like the way the village head candidates are selected (Duryat, 2021; Ikhwan, 2019).

2. The second concept is a little more advanced. This concept sees leadership as a function of the group. Based on this concept, the successful of leadership is not only influenced by one's nature or ability, but rather on the characteristics and nature of the group led (Rohaeni, 2016; Thaib, 2018). Each group has different characteristics and traits, thus a different type of leadership is required (Subhan, 2014). As the position of neighbourhood chairman, that success to manage and lead the society in Lampung, it is not necessarily able if he is given the responsibility to lead as chairman of neighbourhood in Jambi area. It is caused lampung residents have different characteristics and traits with residents of Jambi area.

3. The third concept is more advanced concept, it is not only based on a sociological and psychological view, but it based on politics and economics. On the basis of this concept, leadership is a function of the situation. In addition to the individual nature of the group's leaders and functions such as the first and second concepts, the situation and condition of the group's location or region are also analyzed in leadership issues (Muftitama, 2020; Mulyono, 2018). The third concept shows that no matter how good the nature of leadership in carrying out its functions, the success of the leader is still determined from a dynamic situation and accordance with the changes and development of the life of the group. It is known from culture, customs, social structures and mobility and government politics, it often progresses towards improvement. So do institutions, community organizations and countries. Through, the development and change it demands the development and change in the nature, type and ability to lead (Muflihin, 2008; Pramudyo, 2013). Governors who have succeeded in leading the region in the past, will not necessarily succeed if re-elected to the same position today.Thus, in order to get ideal leadership, the three concepts must be combined because the three complement each other.

\section{Method}

This research is qualitative research, which aims to get a deep interpretation and understanding of the meaning of phenomena in the field. Qualitative approach is a research process by understanding on the basis of methodology and investigation on human problems and social phenomena. In this approach, researchers create complex images, study words, report in detail from the respondent's point of view, and conduct studies on natural conditions. The location of the research about the leadership of the principal in improving the professional competence of teachers is at SMAN 4 OKU. It is implemented approximately six months from May to October 2020. The data was needed in this research was obtained by data collection method through: interview, observation and document study.

\section{Results and Discussions}

During a leadership process, a leader applies a certain type of leadership. An effective type of leadership is a type of leadership that can influence, encourage, direct and mobilize people who are led according to the situation and conditions so that they will work vigorously in achieving organizational goals. 


\section{The Headmaster's Leadership in Improving Teachers' Professional Competence in the Digital Age}

The result of the author's interview with the principal, about the type of leadership from the principal at SMA Negeri 4 OKU, he gave the following answer: "The headmaster as a leader who is able to give a good direction of purpose and example to his subordinates, as the headmaster must also be able to communicate well and have good personality traits such as honesty, confidence, responsibility, and examples. Then from here, his leadership or his leadership style can be exemplified by his subordinates".

The result of the researcher's interview with Pak AP, He is a teacher of Sociology in class X and XII at SMA Negeri 4 OKU about the type of leadership of the principal. He said: "The headmaster often controls the situation of the class to see directly, the teachers who teach, whether the teacher is present or not. And if he/she does not present, whether the teacher has asked permission beforehand. If the teacher is rarely not present, so the headmaster will reprimand the teacher for asking why the teacher does not present and then the headmaster takes action in the form of briefings and warnings".

Furthermore, the author also conducted an interview with one of employee staff, He is Mr. ID on October 16th , 2020 at SMA Negeri 4 OKU regarding the type of principal leadership, he gave the answer: "The headmaster usually has a conversation or hospitality every day, which is talked about the problem that teachers face when teaching. The headmaster does the hospitality before the school starts, or when the teachers are resting and also after teaching". The principal of SMA Negeri 4 OKU also added that the type of leadership is very important and affects the situation and development of the teaching and learning process, such as the way teachers teach that is unpleasant and can raise to students' rejection of teachers. Therefore, it is necessary to analyze the teaching and learning styles of students through teaching training, so based on above, the school, especially the principal, always conducts communication such as private and group conversations with teachers of lesson study, and it is more importantly the school expects the teachers to evaluate and exchange opinions about the teaching process both the good results of teaching and weaknesses in controlling the teaching and learning situation so that they can teach better. Based on observations at October 14th, 2020, as the effort improves the teacher performance, so the headmaster approached the teachers face-to-face specifically to discuss the process of teaching and learning activities, motivate teachers, the school both at the beginning and end does the teacher meeting to discuss and evaluate the results of the teaching and learning process activities and provide information on developing things such as curriculum changes, teaching methods and the use of teaching tools (Irwana, 2015; Sarifudin, 2019; Tanama et al., 2016). In addition, in improving the performance of teachers, the school held trainings such as making RPP, making syllabuses, implementing KTSP and holding seminars on education, the task was carried out by teachers such as the making of RPP, Syllabus, and the implementation of KTSP, but in its implementation was not maximum, then in terms of supervision of the principal teachers carried out control such as, attendance, attendance, time discipline. Furthermore, the efforts is made by the headmaster in improving the teacher performance, it is to make training such as making RPP, syllabus, then provide opportunities to attend educational seminars, in addition the headmaster provides motivation to teachers and supervises the process of teaching and learning activities even if it is only brief, but these trainings are not often done.

Based on observations was done on October 13th, 2020 at SMA Negeri 4 OKU, that in an effort to increase the professionalism of the headmaster motivating teachers before starting teaching, talking with teachers during recess concerning KBM. And on other occasions, teachers are included in KTSP training, syllabus and attend seminars on education.

Conceptually, the indicators of teacher professionalism are: (1) Preparation of learning plans, (2) Implementation of interaction of teaching and learning process, (3) Assessment of student interaction, (4) Implementation of follow-up results of learning achievement assessment, (5) Implementation of guidance and counseling, (6) Work discipline, and (7) Responsibility and loyalty in the task (Prayitno, 2019; Wijaya \& Syamsu Nahar, 2020, 2020).

The findings in this study are in line with the following researches, on the role of principals in SD Negeri 28 Rimau Island in improving professional competencies, namely: a) The principal as the education teacher is tasked with directing and transforming his knowledge to his students (Roqib \& Nurfuadi, 2020). The second study was supported by the results of study conducted which stated that the development of teacher professionalism is directed at improving quality. The criteria for teacher professionalism include ability: mastering materials, managing PBM, managing classes, managing media or resources, mastering the foundation of education, knowing the interaction of teaching and learning, assessing student achievement, knowing the functions and programs of Counseling Guidance services, and getting to know the school administration. In fact, the development of teacher professionalism is emphasized on three basic abilities, they are: professional ability, personal ability and social ability (Nurrahmi, 2015). With the results of his research 
showing that the implementation of supervision of the principal at MI Ma'arif Mayak Tonatan Ponorogo through three stages, namely on supervision planning, supervision implementation and supervision evaluation.

The teacher's social competence needs to be developed so that there is a harmonious relationship between the teacher and the principal, education personnel, students, parents and the community. Harmonious relationships will create a comfortable atmosphere in the school environment, so it can positively affect the achievement of school goals. This condition will also affect the image of the community towards the school.

In conclusion, according to the author, the headmaster's leadership in increasing the professionalism of teachers will be more advanced and develop very well, which is more forward democratic leadership style that is able to effectively improve the work of teachers in improving the professionalism of teachers set in accordance with the rules made by the school, especially the principal, and make improvements so that teacher professionism, quality and quality of school can be achieved. However, the headmaster as leader has duties and responsibilities in carrying out his leadership.

\section{Supporting Factors And Inhibition of Principals In Improving Teacher Professional Competence in the Digital Age}

Based on the results of an interview was conducted by researchers with the principal, Mrs. JM on October 13th, 2020 at SMA Negeri 4 OKU, the supporting and inhibiting factors of the principal's leadership in increasing the professionalism of teachers at SMA Negeri 4 OKU have been running well and sustainably. This is explained in the interview excerpt as follows: "The supporting factor of the headmaster's leadership in improving the professionalism of teachers, that teachers have taught according to their profession, infrastructure also supports while the inhibition factor is some teachers who can not comply with the regulations that have been set"

The same thing was also expressed by one of the Mathematics teachers in grade XII, Mrs. DP on October 13th, 2020 at SMA Negeri 4 OKU regarding the supporting factors and inhibition of the headmaster's leadership in increasing the professionalism of teachers at SMA Negeri 4 OKU, she gave the answer: "The inhibition factors of the headmaster's leadership in improving the professionalism of teachers include some teachers who are less disciplined to comply with the rules applied in school, limited teacher training programs outside office hours, there are also teachers who are inactive and the results of management have not been able to affect colleagues in school".

The results of a researcher interview with a religion teacher, Mrs. MT on October 9th, 2020 at SMA Negeri $4 \mathrm{OKU}$ about the supporting factors and inhibition of the headmaster's leadership in improving the professionalism of teachers at SMA Negeri $4 \mathrm{OKU}$, he gave the answer, "Obstacles or obstacles are limited programs for teacher training outside office hours, because there are still a small number of inactive teachers and the results of management have not been able to affect their friends."

From the results of interviews with principals, math teachers and Religious teachers, it can be concluded that the supporting factors and inhibitions of the headmaster's leadership in increasing the professionalism of teachers at SMA Negeri 4 OKU are obstacles faced such as some teachers who do not comply with school rules such as discipline this also affects the increasing professionalism of teachers in this school and limited programs for training teachers outside of office hours. The supporting factor is adequate facilities and infrastructure. trainings or seminars that are quite often held. Then, the headmaster in increasing the professionalism of teachers, namely by controlling the teachers by looking at attendance, attendance, time discipline but not every day pay attention or see directly the teacher teaching and then evaluate the interaction or see directly the teacher teaching and evaluate the results of the teacher's interaction with the students in class. The principal only provides guidance on duties and obligations, a teacher then rules in oral and written form, and motivates the teachers.

In carrying out his leadership, of course, the headmaster was inseparable from the obstacles encountered in the school. The findings in this study showed that the inhibition factor in improving teacher professional competence are some teachers who do not comply with school rules such as work discipline, late arrival, not making learning devices, not attending class even though they are in school and teachers who are not present without a license / notification. Limited programs for teacher training outside of office hours, there are still some teachers who are not active and the results of the management have not been able to impact their friends.

The solution of the headmaster in improving the competence of the teacher's professionalism is by controlling the teachers through seeing attendance, arrival, time discipline and every day paying attention or seeing the teacher directly and then evaluating the results of the interaction or seeing the teacher directly and evaluating the results of the teacher's interaction with the students in class. The headmaster gave a briefing on 
the duties and obligations of a teacher and then gave the rules in the form of oral and written, as well as motivating the teachers. If it has been done by the headmaster towards subordinates or teachers and if it turns out that there are teachers who still do not heed then the principal will expressly give a summons letter (SP) to the teacher concerned to be given more guidance so that in the future the headmaster's efforts to improve the professional competence of the teacher will be even better (Muftitama, 2020).

\section{Conclusions}

The conclusions result of this research was obtained that the implementation of the type of leadership of the principal at SMA Negeri 4 OKU by the principal received a good response from subordinates, it's namely democratically, he always gave a good example to the teacher, so there is an improvement in the competence of the teacher's personality, delegate the teachers incidental related to the duties of officially and provide motivation to students, and open attitude becomes a place of consultation and implementation through decision making related to increasing the professionalism of teachers through meetings or deliberations, show how the way teachers are happy to carry out the verdict and feel satisfaction, and the responsibility of implementing the decision is charged to all teachers or all meeting participants. The supporting factor of the principal's leadership type in improving the professional competence of teachers at SMA Negeri 4 OKU is adequate from infrastructure facilities, thus supporting the teaching, training or learning process in schools. Furthermore, the obstacles encountered include, the limitations of teacher training programs outside office hours, there are still some teachers who are not active, and the results of the training can not affect their friends, then in the rules that have been determined there are still teachers who are less disciplined.

\section{References}

Ananda, R., \& Banurea, O. K. (2017). Manajemen sarana dan prasarana pendidikan.

Dahlan. (2014). Kamus Ilmiah. Surabaya : Arkola.

Djafar, D. . (2013). Hakikat Kepemimpinan. Bandung: Alfabeta.

Duryat, H. M. (2021). Kepemimpinan Pendidikan: Meneguhkan Legitimasi Dalam Berkontestasi Di Bidang Pendidikan. Penerbit Alfabeta.

Ikhwan, A. (2019). Sistem kepemimpinan islami: instrumen inti pengambil keputusan pada lembaga pendidikan islam. Istawa: Jurnal Pendidikan Islam, 3(2), 111-154.

Irwana, A. (2015). Kepemimpinan visioner kepala sekolah dan kinerja guru terhadap efektivitas sekolah di sekolah dasar. Jurnal Administrasi Pendidikan, 22(2).

Kristiawan, M., Safitri, D., \& Lestari, R. (2017). Manajemen Pendidikan (Y. Deepublish (ed.)).

Muflihin, M. H. (2008). Kepemimpinan Pendidikan: Tinjauan terhadap Teori Sifat dan Tingkah-laku. INSANIA: Jurnal Pemikiran Alternatif Kependidikan, 13(1), 67-86.

Muftitama, A. (2020). Strategi Komunikasi Kepemimpinan \& Manajemen Konflik dengan Konsep LCCVASE (Listening, Clarifying, Confirming, Verifying, Action-Solving, Evaluating). Ishlah: Jurnal Ilmu Ushuluddin, Adab Dan Dakwah, 2(2), 128-158.

Mulyasa. (2004). Manajemen Berbasis Sekolah. Remaja Rosdakarya.

Mulyono, H. (2018). Kepemimpinan (Leadership) Berbasis Karakter Dalam Peningkatan Kualitas Pengelolaan Perguruan Tinggi. Jurnal Penelitian Pendidikan Sosial Humaniora, 3(1), 290-297.

Nurrahmi, H. (2015). Kompetensi Profesional Guru Bimbingan Dan Konseling. Al-Hikmah, 9(1), 45-55. https://doi.org/10.24260/al-hikmah.v9i1.87

Pramudyo, A. (2013). Implementasi manajemen kepemimpinan dalam pencapaian tujuan organisasi. Jurnal Bisnis, Manajemen, Dan Akuntansi, 1(2).

Prayitno, P. J. (2019). Pelaksanaan Supervisi Akademik Untuk Meningkatkan Kompetensi Pedagogik Guru SMA. Jurnal Visi Ilmu Pendidikan, 11(2), 46-55.

Rivai, \& Murni. (2010). Education Managemen. Jakarta: Raja Grafindo Persada.

Rohaeni, H. (2016). Model gaya kepemimpinan dan motivasi terhadap kinerja pegawai. Jurnal ECODEMICA, $4(1), 32-47$.

Roqib, M., \& Nurfuadi, N. (2020). Kepribadian guru. CV. Cinta Buku. 
Sarifudin, S. (2019). Implementasi supervisi kepala sekolah terhadap kinerja guru dalam upaya meningkatkan kualitas pembelajaran di madrasah ibtidaiyah negeri (min) kota bogor. Islamic Management: Jurnal Manajemen Pendidikan Islam, 2(01), 49-70.

Subhan, M. (2014). Kepemimpinan islami dalam peningkatan mutu lembaga pendidikan islam. TADRIS: Jurnal Pendidikan Islam, 8(1), 125-140.

Sumarni, S., \& Tamsah, H. (2017). Pengaruh supervisi akademik pengawas sekolah, kepemimpinan kepala sekolah dan lingkungan kerja terhadap kinerja guru smk negeri se-kecamatan tamalate kota makassar. Jurnal Mirai Management, 2(1), 149-163.

Sumitro. (2012). Perilaku Organisasi. Bandung: Alfabeta.

Tanama, Y. J., Supriyanto, A., \& Burhanuddin, B. (2016). Implementasi Supervisi Klinis dalam Meningkatkan Profesionalisme Guru. Jurnal Pendidikan: Teori, Penelitian, Dan Pengembangan, 1(11), 22312235.

Thaib, M. I. (2018). Kepemimpinan Pendidikan dalam Islam. Intelektualita, 4(1).

Wijaya, C., \& Syamsu Nahar, A. A. (2020). IMPLEMENTASI SUPERVISI PEMBELAJARAN DALAM MENINGKATKAN PRESTASI KERJA GURU PENDIDIKAN AGAMA ISLAM DI SMP NEGERI 2 RANTAU SELATAN KABUPATEN LABUHANBATU. EDU-RILIGIA: Jurnal Ilmu Pendidikan Islam Dan Keagamaan, 4(1). 